\title{
ZBTB48 wt Allele
}

National Cancer Institute

\section{Source}

National Cancer Institute. ZBTB48 wt Allele. NCI Thesaurus. Code C52934.

Human ZBT B48 wild-type allele is located in the vicinity of 1 p36.3 and is approximately 9 $\mathrm{kb}$ in length. The allele, which encodes zinc finger and BT B domain containing protein 48, plays a role in RNA polymerase II-directed transcription. 